University for Business and Technology in Kosovo

UBT Knowledge Center

Nov 2nd, 9:00 AM - Nov 3rd, 5:00 PM

\title{
Marketing of a destination. Critical factors of a destination marketing success from of Stakeholders' and customer' perspective. The case of Macedonia and Albania
}

Jovan Stojanoski

Ohrid, Macedonia

Liljana Elmazi

University of Tirana

Follow this and additional works at: https://knowledgecenter.ubt-uni.net/conference

Part of the Business Commons

\section{Recommended Citation}

Stojanoski, Jovan and Elmazi, Liljana, "Marketing of a destination. Critical factors of a destination marketing success from of Stakeholders' and customer' perspective. The case of Macedonia and Albania" (2012). UBT International Conference. 46.

https://knowledgecenter.ubt-uni.net/conference/2012/all-events/46

This Event is brought to you for free and open access by the Publication and Journals at UBT Knowledge Center. It has been accepted for inclusion in UBT International Conference by an authorized administrator of UBT Knowledge Center. For more information, please contact knowledge.center@ubt-uni.net. 


\title{
Project Management and Role of Human Resources
}

\author{
Prof. Besnik Skenderi, MBA (dr. Candidate) ${ }^{1}$ \\ ${ }^{1}$ University for Business and Technology \\ besnik_skenderi@yahoo.com
}

\begin{abstract}
This paper is about project management and impact of human resources and training regarding the successful project management. In the first part author discuss about project management, role of the project manager and about project, management standards that are implemented by privately owned companies and state owned enterprises. In the second part author had conducted a brief literature review about professional knowledge of project managers and impact of training for project managers and for the project team members. In the last part, author had provided conclusion and recommendations.
\end{abstract}

Keywords: Project, PMP, PRINCE2, Training

\section{Projects}

Because of technological innovations, competition, and new product development privately owned companies and state owned enterprises are conduction business operations that are different from their daily operations. Those operations are conducted in a form of projects. Literature provides lot of definitions for the project and conclusion can me that project is a temporary organization that has do deliver products, based on specific business case and it has limited resources. Around $70 \%$ of projects that are implemented are failing and some of them are failed projects before the implementation begin.

Project management professional manages projects, and those professionals during the project life cycle are known as project managers. Many companies are appointing project managers after the project has been approved, and in this case, project manager is not taking part on process of business analysis. Despite this, some companies are appointing project managers base $d$ on their technical competencies and they are ignoring the project managers interpersonal and leadership skills. Ano ther is sue that is related with the project management is fact that many companies expect from the project team members to understand the project management terminology and to adopt within project management process and techniques.

Companies are investing a lot on projects; however, companies are also investing on capacity building for project management. In some countries, state owned companies are obliged by the law to follow specific logical framework for project management. For example in England all state owned companies are obliged to implement projects according to PRINCE2 (Projects In Controlled Environments) logical framework, and this logical framework was developed by OGC (Office of Government Commerce). While in the US (United States), PMI (Project Management Institute) had developed another logical framework for project management, PMP (Project Management Professional).

\section{Literature review}

Damaré, (2008) states that "Project managers, business analysts, and contract managers often work in silos — each handling one piece of the project management pie. (p.47). Because of this it is important that all project team members, understand the project goals and it is also important that all project team members understand the responsibilities and duties of all project team members since all of them are working for the same goal. In order to achieve this many companies train their staff in a field of project management. Some companies are sub-contracting other companies to conduct the training while other companies are conducting the in house training. However, the process of organizing training is not a simple process, companies and their hu man resource departments should select the right people to send in the training. (Tecău and Chitu, 2011, Dulaimi, 2005). It is important to select the right people since companies employs people with the different professional background and according to Dulaimi, (2005), people with the technical professional background are focusing more on technical details rather on social interaction with other project team members.

Wang and Shen, (2012) are recommending that university educated employees, should receive a professional management training and they should gain the experience before they are appointed to the position of project manager. Other researchers, Carbone and Gholston, (2004) are mention the fact that many companies are conducting on job training for their project managers and that is expected from them to learn project management skills while they are doing the job. This step is associated with the risks that could lead to the project failure, since project managers would not be able to check validity of the business case, and to conduct proper risk analysis and to communicate with the stakeholders. 
Another issue is the content of the training, nowadays many universities and other education providers are offering project management training programs and certifications. For example in a single query for project management training in the Google search engine 197 million results are appearing

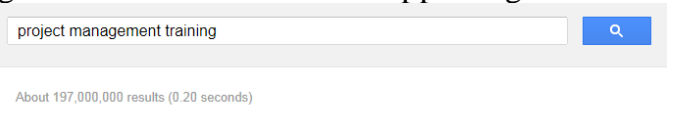

Figure 29, result for project management training in Google

However, project management trainings should be consistent with the company goals, since according to Rehman, and Khan, and Khan, (2011 " indicator of ineffective training and development systems is No clear link between training and organizational goals or plans' (p.43), while Birkenkrahe and, Quade, and Habermann, (2011) concludes that "the standard training material is rarely used".(p.36). Another identified issue is that in most cases training are conducted by business consultants that have lack of didactic skills.

Role of human resources department is evident for the successful implementation of training for the project management. However PMP training and certification, remain the most valuable training for project management professionals, since it consists from academic knowledge and from best project management practices. Number of PMP is increasing and for many companies this certification is an entry level for project managers. However, the rapid changes in the IT (information technology) is influencing also the field of project management. Regarding this issue Fisher, and Schluter, and Toleti, (2005) concludes that "as project management technology has evolved, the industry has developed better computerization tools to control project budgets and schedules. Yamín and Harmelink (2001) provide similar conclusions, since with the use of improved project management methods and electronic supporting tools the ability to manage project has improved.

\section{Conclusion}

Nowadays many companies are implementing projects and even some of the companies are establishing project management offices in order to support project implementation in the process -oriented companies. Despite the large accumulated knowledge and experience business are facing with the large number of failed projects. One of the reason why the projects a re failing is fact that companies are appointing project managers after the projects are approved and in many cases companies are training only the project managers, while the rest of the project team member are being allocated to the project without atte nding any formal training for project management. Because of this project, team members are not familiar with the project management professional terminology and they are not able to follow instructions and to follow the procedures during the project life cycle. In order to avoid this and to establish standards in the field of project management, bodies of knowledge had created the PMP curriculum and certification. PMP is the most valuable certification in the field of project management. With the use of a vailable software's, process of project management is much easier and in a same time, it provides just in time information regarding the project progress, resource allocation and cost.

Companies should train all their staff in a field of project management and they should not focus only in the project managers. Even that it may look that companies will waste their resources in a long term companies will have a benefit. After the successful training is implemented, all staff members will know which procedures should follow and which steps and which business analysis they should conduct before they initiate a project.

\section{References}

1. Birkenkrahe, M., Quade, S., \& Habermann, F. (2011). Improving collaborative learning and global project management in small and medium enterprises. International Journal of Advanced Corporate Learning, 4(4), 32-37.

2. Carbone, T. A., \& Gholston, S. (2004). Project manager skill development: a survey of programs and practitioners. Engineering Management Journal, 16(3), 10-16.

3. Damaré, B. (2008). Workplace learning to improve IT project managament. The Public Manager, 45-50.

4. Dulaimi, M. F. (2005). The influence of academic education and formal training on the project manager's behavior. Journal of Construction Research, 6(1), 179-193.

5. Fisher, D. J., Schluter, L., \& Toleti, P. K. (2005). Project management education and training process for career development. Journal Of Construction Engineering And Management, 131 (8), 903-910.

6. Kerzner, H. (2009). Project management a system approach to planning, scheduing and controlling. John Wiley \& Sons, Inc.

7. Rehman, A. U., Khan, A. M., \& Khan, R. A. (2011). Measuring Training effectiveness a case study of public sector project management in pakistan. Journal of Diversity Manaeement, 6(1), 39-48. 
8. Tecău, S. A., \& Chitu, I. B. (2011). The impact of participating in european union financed training programmes over the acquisition of necessary knowledge in order to attract and manage successful projects. Bulletin of the Transilvania University of Braşov, 4(53), 69-76.

9. Wang, X., \& Shen, J. (2012). An investigation into the professional commitment of chinese project management professionals. International Journal of Business and Management, 7(10), 156-166. 